\title{
Commentary: Autologous Peripheral Blood Stem Cells (PBSC) are Safe and Effective in Knee Osteoarthritis
}

\author{
Konstantinos I. Papadopoulos ${ }^{1 *}$ and Thana Turajane ${ }^{2}$ \\ ${ }^{1}$ THAl StemLife Co., Ltd, Bangkok, Thailand, ${ }^{2}$ Department of Orthopedics, Police General Hospital, Bangkok, Thailand
}

Keywords: osteoarthritis, knee, peripheral blood, stem cells, granulocyte colony stimulating factor hG-CSF, leukapheresis, autologous, PBSC

\section{A Commentary on}

The Use of Peripheral Blood-Derived Stem Cells for Cartilage Repair and Regeneration In Vivo: A Review

by Chen, Y.-R., Yan, X., Yuan, F.-Z., Ye, J., Xu, B.-B., Zhou, Z.-X. et al. (2020). Front. Pharmacol. 11: 404. doi:10.3389/fphar.2020.00404

\section{OPEN ACCESS}

Edited by:

Roberto Paganelli,

University of Studies G.d'Annunzio Chieti and Pescara, Chieti, Italy

Reviewed by: Aurelio Muttini,

University of Teramo, Italy Livia Roseti, Rizzoli Orthopedic Institute (IRCCS),

Italy

*Correspondence: Konstantinos I. Papadopoulos kostas@thaistemlife.co.th

Specialty section:

This article was submitted to Translational Pharmacology, a section of the journal

Frontiers in Pharmacology

Received: 13 January 2021 Accepted: 22 February 2021

Published: 20 April 2021

Citation:

Papadopoulos Kl and Turajane T (2021) Commentary: Autologous Peripheral Blood Stem Cells (PBSC) are Safe and Effective in Knee Osteoarthritis.

Front. Pharmacol. 12:652738. doi: 10.3389/fphar.2021.652738

\section{INTRODUCTION}

We read with interest the review of Chen et al. "The Use of Peripheral Blood-Derived Stem Cells for Cartilage Repair and Regeneration In Vivo: A Review" (Chen et al., 2020). Meta-analyses are a key component of evidence-based health care that by pooling together selected randomized controlled trials (RCTs) calculate an overall estimate or of the effect of the intervention under consideration (Moher and Olkin, 1995). The present review only includes one human RCT.

\section{MATERIALS AND METHODS}

We believe that our RCT in 60 early osteoarthritis patients (of which 40 were actively treated with autologous hG-CSF activated PBSC and 20 received conventional hyaluronic acid treatment) (Turajane et al., 2017) should have been included. Our RCT showed statistically significant avoidance of total knee arthroplasty, and potent, early, and sustained symptom alleviation. Furthermore, our in vitro investigation (Turajane et al., 2014) shed light on the autologous PBSC mechanism of action by confirming chondrogenic differentiation potential for autologous PBSC through potentiated Sox9 transcription resulting in sequential COL-2 and aggrecan mRNA increases that ultimately resulted in histologically confirmed increased proteoglycan and glycosaminoglycan content in newly formed hyaline cartilage.

\section{DISCUSSION}

We thus believe that the results presented in the current metanalysis are incomplete since the omitted patient number is half of the included ( 55 omitted vs. 130 included) (Jancewicz et al., 2004; Saw et al., 2011; Skowroński et al., 2012; Saw et al., 2013; Skowroński and Rutka, 2013; Turajane et al., 2013; Fu et al., 2014a; Saw et al., 2015). Comprising the 2017 RCT of Turajane et al. (Turajane et al., 2017) would have included a 
second RCT in the review, thus considerably strengthening the conclusion that autologous PBSCs show superiority in procurement, safety, and positive therapeutic effects in clinical settings where cartilage repair and regeneration are required.

\section{REFERENCES}

Chen, Y. R., Yan, X., Yuan, F. Z., Ye, J., Xu, B. B., Zhou, Z. X., et al. (2020). The use of peripheral blood-derived stem cells for cartilage repair and regeneration in vivo: a review. Front. Pharmacol. 11, 404. doi:10.3389/fphar.2020.00404

Fu, W. L., Ao, Y. F., Ke, X. Y., Zheng, Z. Z., Gong, X., Jiang, D., et al. (2014a). Repair of large full-thickness cartilage defect by activating endogenous peripheral blood stem cells and autologous periosteum flap transplantation combined with patellofemoral realignment. Knee 21, 609-612. doi:10.1016/j.knee.2013.10.010

Jancewicz, P., Dzienis, W., Pietruczuk, M., Skowroński, J., and Bielecki, M. (2004). Osteochondral defects of the talus treated by mesenchymal stem cell implantation-early results. Rocz Akad Med. Bialymst. 49 (Suppl. 1), 25-27.

Moher, D., and Olkin, I. (1995). Meta-analysis of randomized controlled trials. JAMA 274 (24), 1962-1964. doi:10.1001/jama.1995.03530240072044

Saw, K. Y., Anz, A., Merican, S., Tay, Y. G., Ragavanaidu, K., Jee, C. S. Y., et al. (2011). Articular cartilage regeneration with autologous peripheral blood progenitor cells and hyaluronic acid after arthroscopic subchondral drilling: a report of 5 cases with histology. Arthroscopy 27, 493-506. doi:10.1016/j.arthro.2010.11.054

Saw, K. Y., Anz, A., Siew-Yoke Jee, C., Merican, S., Ching-Soong Ng, R., Roohi, S. A., et al. (2013). Articular cartilage regeneration with autologous peripheral blood stem cells versus hyaluronic acid: a randomized controlled trial. Arthroscopy 29, 684-694. doi:10.1016/j.arthro.2012.12.008

Saw, K. Y., Anz, A., Jee, C. S. Y., Ng, R. C. S., Mohtarrudin, N., and Ragavanaidu, K. (2015). High tibial osteotomy in combination with chondrogenesis after stem cell therapy: a histologic report of 8 cases. Arthroscopy 31, 1909-1920. doi:10. 1016/j.arthro.2015.03.038

Skowroński, J., and Rutka, M. (2013). Osteochondral lesions of the knee reconstructed with mesenchymal stem cells-results. Ortop. Traumatol. Rehabil. 15, 1. doi:10.5604/15093492.1058409

Skowroński, J., Rutka, M., and Skowroński, R. (2012). Cartilage lesions of the knee treated with blood mesenchymal stem cells-results. Ortop. Traumatol. Rehabil. 14, 1-10. doi:10.5604/15093492.1012404

\section{AUTHOR CONTRIBUTIONS}

All authors listed have made a substantial, direct, and intellectual contribution to the work and approved it for publication.

Turajane, T., Chaweewannakorn, U., Larbpaiboonpong, V., Aojanepong, J., Thitiset, T., Honsawek, S., et al. (2013). Combination of intra-articular autologous activated peripheral blood stem cells with growth factor addition/preservation and hyaluronic acid in conjunction with arthroscopic microdrilling mesenchymal cell stimulation Improves quality of life and regenerates articular cartilage in early osteoarthritic knee disease. J. Med. Assoc. Thai 96, 580. doi:10.1109/JPROC.2015. 2471838

Turajane, T., Chaveewanakorn, U., Fongsarun, W., Aojanepong, J., and Papadopoulos, K. I. (2017). Avoidance of total knee arthroplasty in early osteoarthritis of the knee with intra-articular implantation of autologous activated peripheral blood stem cells versus hyaluronic acid: a randomized controlled trial with differential effects of growth factor addition. Stem Cell Int. 2017, 8925132. doi:10.1155/2017/8925132

Turajane, T., Thitiset, T., Honsawek, S., Chaveewanakorn, U., Aojanepong, J., and Papadopoulos, K. I. (2014). Assessment of chondrogenic differentiation potential of autologous activated peripheral blood stem cells on human early osteoarthritic cancellous tibial bone scaffold. Musculoskelet. Surg. 98, 35-43. doi:10.1007/s12306-013-0303-y

Conflict of Interest: KP was employed by THAI StemLife Co., Ltd.

The remaining author declares that the research was conducted in the absence of any commercial or financial relationships that could be construed as a potential conflict of interest.

Copyright (C) 2021 Papadopoulos and Turajane. This is an open-access article distributed under the terms of the Creative Commons Attribution License (CC $B Y)$. The use, distribution or reproduction in other forums is permitted, provided the original author(s) and the copyright owner(s) are credited and that the original publication in this journal is cited, in accordance with accepted academic practice. No use, distribution or reproduction is permitted which does not comply with these terms. 